\title{
Can the use of varenicline improve the efficacy of pharmacotherapy for nicotine addiction?
}

\author{
Czy zastosowanie warenikliny stanowi szansę na poprawienie skuteczności farmakoterapii
} uzależnienia od nikotyny?

\section{Rafał Mazur ${ }^{1} \mathrm{DF}$, Sebastian Masternak ${ }^{1} \mathrm{BE}$, Michał Pająk ${ }^{1} \mathrm{AE}$, Nikodem Skoczeń ${ }^{2} \mathrm{AD}$, https://orcid.org/0000-0002-9405-9841, Ewelina Soroka² DE, https://orcid.org/0000-0001-6909-2749, Marcin Olajossy²ADF, https://orcid.org/0000-0002-1001-3185}

${ }^{1}$ Student Scientific Association by the II Department of Psychiatry and Psychiatric Rehabilitation, Medical University of Lublin

${ }^{2}$ II Department of Psychiatry and Psychiatric Rehabilitation, Medical University of Lublin

\begin{abstract}
Introduction: Smoking is a huge medical and social problem in Poland, with as many as about $24 \%$ of Poles being addicted to nicotine. Approximately 6 million people worldwide die every year from conditions that are closely related to tobacco addiction, such as cancer and cardiovascular, metabolic or lung diseases. The difficulty in combatting nicotine dependence is largely due to the complex mechanism of this addiction. The motivation of a patient to quit smoking is of great importance in the difficult withdrawal process. Strengthening this motivation is one of the most important tasks of physicians and addiction therapists.

Overview of literature: Nicotine replacement therapy (NRT) has been the most widely known way to break away from smoking addiction for many years now. It involves delivering nicotine to the body in ways that are less harmful than through tobacco smoke. As a consequence, the cravings for nicotine are reduced, making it easier for the patient to break with the addiction. Clinical trials have shown that the use of NRT is associated with a 50-70\% increased chance of maintaining abstinence from smoking compared to placebo. There are many NRT products, including nicotine chewing gum, nicotine patches, lozenges, dissolvable nicotine sticks, or inhalers. Bupropion is a selective dopamine-noradrenaline reuptake inhibitor. This drug is one of the most commonly used in the pharmacotherapy of depression in the United States. At the same time, it has been found to have a positive effect on people trying to break up with the habit of smoking cigarettes. The mechanism of action remains unknown in this case, but studies clearly indicate the efficacy of bupropion, which is comparable to the efficacy of NRT. Varenicline is a partial agonist selective for $\alpha 4 \beta 2$ nicotinic acetylcholine receptors. It has a higher affinity for these receptors than nicotine. By stimulating them, it causes an increase in dopamine secretion (but to a lesser extent than cigarette smoking), helping in this way ease withdrawal symptoms.

Conclusions: Varenicline has higher efficacy than bupropion and NRTs. Simultaneous use of two NRT forms increases the effectiveness of this method to a level comparable to varenicline. Contrary to previous reports, it seems that varenicline does not increase self-aggressive behaviour and the risk of suicide. The effectiveness of antinicotinic drugs depends on the sex of the patient. For both sexes, the most effective drug is varenicline. It is slightly more effective in women than in men. By contrast, NRT and bupropion show greater therapeutic potential in men.
\end{abstract}

Keywords: smoking cessation, nicotine replacement therapy, varenicline, bupropion, cytisine

\section{Streszczenie}

Wstęp: Palenie papierosów jest ogromnym problemem medycznym i społecznym w Polsce, ponieważ około 24\% Polaków uzależnionych jest od nikotyny. Szacunkowo 6 milionów ludzi na świecie umiera rocznie z powodu chorób, które pozostają w ścisłym związku z nałogiem - takich jak nowotwory, choroby układu krążenia, choroby metaboliczne czy choroby płuc. Trudność w przezwyciężeniu nałogu jest spowodowana w znacznej mierze złożonym mechanizmem uzależnienia. Ogromne znaczenie w trudnym procesie wychodzenia z nałogu ma motywacja pacjenta do porzucenia palenia. Wzmacnianie tej motywacji 
jest jednym z najistotniejszych zadań lekarzy wielu specjalności i terapeutów uzależnień.

Omówienie danych z literatury: Najszerzej poznanym farmakologicznym sposobem wspomagania wychodzenia z nałogu palenia papierosów od wielu lat pozostaje nikotynowa terapia zastępcza (NRT). Polega ona na dostarczeniu nikotyny do organizmu w sposób mniej szkodliwy niż poprzez dym tytoniowy. W konsekwencji zmniejsza się potrzeba palenia papierosów, co prowadzić ma do powstania korzystnych warunków do całkowitego zerwania z nałogiem. Badania kliniczne wykazały, że stosowanie NRT wiąże się ze zwiększoną o 50-70\% szansą na utrzymanie abstynencji od palenia tytoniu w porównaniu z placebo. Istnieje wiele metod przyjmowania terapii zastępczej, są to gumy do żucia z nikotyną, plastry nikotynowe, pastylki do ssania, listki rozpuszczalne w jamie ustnej czy inhalatory. Bupropion to selektywny inhibitor wychwytu zwrotnego dopaminy $\mathrm{i}$ noradrenaliny. Lek ten jest jednym z najczęściej stosowanych w farmakoterapii depresji w Stanach Zjednoczonych. Jednocześnie dostrzeżono jego pozy tywny wpływ na osoby, próbujące zerwać z nałogiem palenia papierosów. Mechanizm działania pozostaje w tym przypadku nieznany, jednak badania wskazują jednoznacznie na skuteczność bupropionu, która jest porównywalna ze skutecznością NRT. Wareniklina jest selektywnym, częściowym agonistą acetylocholinergicznych receptorów nikotynowych $\alpha 4 \beta 2$. Substancja ta ma wyższe powinowactwo do tych receptorów niż nikotyna. Pobudzając je powoduje wzrost wydzielania dopaminy, lecz w niższym stopniu niż w przypadku palenia papierosów, co powoduje zmniejszenie abstynencyjnych objawów odstawienia.

Wnioski: Wareniklina wykazuje wyższą skuteczność niż bupropion i poszczególne formy NRT. Przyjmowanie NRT w dwóch formach równocześnie powoduje wzrost skuteczności tej metody do poziomu porównywalnego z warenikliną. Wbrew wcześniejszym doniesieniom, wydaje się, że wareniklina nie wzmaga zachowań autoagresywnych i nie zwiększa ryzyka samobójstwa.Skuteczność leków zależy od płci pacjenta. Dla obu płci substancją o największej efektywności jest wareniklina. Jest ona nieco skuteczniejsza w grupie kobiet, podczas gdy NRT i bupropion wykazują większy potencjał terapeutyczny u mężczyzn.

Słowa kluczowe: rzucanie palenia, nikotynowa terapia zastępcza, wareniklina, bupropion, cytyzyna

\section{Introduction}

Cigarette smoking is a common problem in Poland, with as many as $24 \%$ of Poles being addicted to nicotine [1]. An estimated 6 million people in the world die every year because of diseases that are closely related to smoking addiction, including cancer and cardiovascular, metabolic, and lung diseases. In the twentieth century alone, almost 100 million deaths were caused by tobacco smoking [2,3]. Smokers inhale about 7,000 chemical compounds with cigarette smoke, many of which are carcinogenic [3]. A study conducted in the United States demonstrated that smoking was associated with specific case fatality rates. As much as $87 \%$ of deaths among lung cancer patients, $61 \%$ of deaths among lung disease patients and $32 \%$ of deaths among coronary disease patients were associated with smoking. Despite being highly aware of the harmful effects of tobacco, many addicts are unable to quit smoking permanently. The difficulty in combating nicotine dependence is due to the complex mechanism of addiction. Inhalation of tobacco smoke causes a very rapid increase in blood plasma concentrations of nicotine, what leads to the stimulation of neuronal $\alpha 4 \beta 2$ nicotinic acetylcholinergic receptors. This results in the release of dopamine into the nucleus accumbens, which is a components of the reward system. Regularly consumed, nicotine deregulates basal dopamine release. In people who abruptly quit smoking, this deregulation results in symptoms of withdrawal syndrome, caused by a decrease in dopamine concentration in the body.
Repeated association of cigarette smoking with pleasure leads to the development of another type of addiction - a psychological one [3]. It should be emphasized that the patient's motivation to quit smoking is of great importance in the difficult process of getting out of the addiction. Boosting of this motivation is one of the most important tasks of physicians and addiction therapists. It can be observed that many patients decide to give up smoking in the face of a sudden life-threatening illness, especially acute coronary syndrome. Properly built and maintained therapeutic contact is one of the foundations of cooperation with a person addicted to nicotine and can, to a large extent, determine the success of therapy.

\section{Overview of literature}

According to the statistics published by the public opinion research institute TNS Polska, the number of smokers trying to fight addiction increases year by year [4]. From September 2014 to 2015, 25\% of smoking women and $31 \%$ of smoking men in Poland made an attempt at quitting smoking. The cessation success was comparable in both groups at around 36\%. Many nicotine addicts fail to part with cigarettes by using strong will only, and so they resort to various supportive methods, both scientific and grounded in alternative medicine. Among techniques with proven efficacy, the leading role is played by pharmacotherapy. Recently, however, behavioural cognitive psychotherapy has also become popular, which is especially effective when it is adapted to the patient's 
race, culture, and religion [4].

As an interesting side note, there have also been attempts to treat nicotine dependence using bioresonance. Bioresonance therapy was first used in Germany in the 1970s. The bioresonance device consists of a computer and four electrodes - two held by the patient in the hands and two touching his/her feet. The electrodes receive natural low frequency electromagnetic signals (waves) emitted by the human body. The computer amplifies the signals received from the electrodes, sometimes inverting their phase, and sends them back to the body to superimpose them on the patient's natural electromagnetic oscillation field [5]. According to bioresonance therapists, two to three bioresonance sessions are enough for a smoker to quit smoking effectively. Although this procedure is often considered pseudoscientific, there are studies which confirm its effectiveness in smoking cessation. Pihtilia and colleagues demonstrated that cessation success rates were significantly higher in subjects treated with bioresonance than in control subjects treated with simulated bioresonance. Importantly, the percentages of people who abstained from smoking one week, two weeks, one month, and one year after the procedure, were consistently higher in the active bioresonance group [6].

The main focus of the present article, however, is pharmacotherapy. The beginnings of this treatment path go back to the 1930s when attempts were made to treat nicotine dependence with lobelin [7], which is a kind of substitute for nicotine. Since then, there has been some progress in addiction pharmacology, and today we know more substances that help fight addiction. They work through various mechanisms and are used in numerous forms and doses. We discuss the most important of them below.

\section{Nicotine replacement therapy}

Nicotine replacement therapy (NRT) is one of the best researched methods of helping people recover from the smoking habit. In NRT, nicotine is delivered to the body in ways that are less harmful than through tobacco smoke. As a consequence, the cravings for nicotine are reduced, making it easier for the patient to break with the addiction. Clinical studies have shown that NRT is associated with $50-70 \%$ higher abstinence rates compared to placebo [8]. There are many nicotine replacement aids, such as nicotine chewing gums, nicotine patches, lozenges, dissolvable nicotine sticks, or inhalers. The choice depends on the user's personal preferences. The individual NRT products show comparable efficacy [9]. The advantage of chewing gum and lozenges is that chewing and sucking replace the action of smoking a cigarette. They can in this way replace the habit of "popping out for a cigarette". The nicotine content in the gum or lozenge is small, which means they have to be used many times a day. The disadvantage of these products is that they can cause hiccups, salivation and irritation in the oral cavity [10]. Nicotine patches are an NRT aid with proven safety and efficacy [11]. Their unquestionable advantage is the ease of use. The patch is applied daily by sticking to the skin; nicotine is released from it continuously, and slower than in the case of other forms of NRT [12]. The patches are available in various dosages; they are kept on the skin for 16 or 24 hours. Side effects include local skin reactions at the site of contact and sleep disturbances when a 24-hour version is used [13]. The question of the use of NRT in pregnant women remains controversial. Research shows that replacement therapy during gestation is only justified if the woman is unable to stop smoking on her own. NRT in such cases is used to limit the exposure of the foetus to other substances found in cigarette smoke and to make it easier for the mother to break with the addiction [14]. Studies on cotinine levels in pregnant smokers showed that women who used NRT had about 30\% lower concentrations of this compound than those who continued smoking cigarettes. In addition, it has been shown that the use of replacement therapies reduces the risk of low birth weight in the child and preterm delivery compared to women who continue smoking during pregnancy [15]. However, the most effective way to protect the foetus is to stop smoking altogether without taking nicotine in any other form.

Studies of a cohort of addicted adolescents aged 12-18 showed that NRT was ineffective in this age group. After 12 months from the beginning of the experiment, NRT showed similar efficacy to placebo in these patients [16].

Taking nicotine medications carries the risk of side effects related to high levels of nicotine in the blood. Toxic doses of nicotine can, in extreme cases, lead to fatal respiratory depression. However, it has been demonstrated in a large cohort study that compliance with the recommended doses of NRT does not involve the risk of overdose [17].

\section{Bupropion}

Among the agents that can be used to treat nicotine addiction, there is a group of drugs which were originally designed to treat depressive disorders. The most commonly used medication in this group is bupropion. It is one of the most commonly used drugs in the pharmacotherapy of depression in the United States. Bupropion is a selective norepinephrine-dopamine reuptake inhibitor. Apart from its anti-depressant action, however it has also been observed to exert a positive effect on quitters. The mechanism of action remains unknown in 
this case, however, studies clearly show that bupropion has an efficacy comparable to that of NRT [18]. In comparison to NRT users, however, bupropion users are more likely to maintain long-term abstinence and experience a smaller increase in body weight caused by smoking cessation $[19,20]$. It has been demonstrated that the effectiveness of treatment with this medication is independent of whether the patient has experienced or is experiencing depressive symptoms. Therapy should last a minimum of 7 weeks, but it can last up to a year. The most serious side effect of the drug is an increased risk of seizures, which is why it cannot be used in people with risk factors such as epilepsy, head injuries, use of medications which lower the seizure threshold, diabetes, or alcohol dependence. Other side effects include dry mouth, insomnia, headaches, and gastrointestinal symptoms. Serious complaints are rare, however, which is why bupropion is considered as safe medication [21]. Studies on the use of bupropion during pregnancy have shown that it has no negative impact on the foetal or maternal metabolic processes; however, there are reports of an increased risk of heart disease in the child [22]. Because there are too few reports regarding the use of the drug during pregnancy, bupropion is indicated only in the treatment of severe depressive episodes.

\section{Varenicline}

Undoubtedly, one drug that is worth paying attention to is varenicline, which according to research, is one of the most effective pharmaceutical interventions for treating nicotine addiction, moreover, the results of many studies show that it specifically inhibits the search for alcohol in laboratory animals [23,51, 52, 53]. Despite its high efficacy, it is not as popular as NRTs or bupropion. Varenicline is a partial agonist selective for $\alpha 4 \beta 2$ nicotinic acetylcholine receptors. It has a higher affinity for these receptors than nicotine. By stimulating them, it causes an increase in dopamine secretion (but to a lesser extent than cigarette smoking), helping in this way ease withdrawal symptoms [24]. Treatment is best started one week before the previously scheduled quitting date [25]. During this period the body becomes saturated with the drug, administered at a lower dose, which leads to long-term reduction of side effects - mainly nausea. In a study by Hajek et al., the preloading period was extended from one to four weeks. Twelve weeks post cessation, the abstinence rates in the experimental group were significantly higher $(47.2 \%)$ than in patients treated as per current guidelines (20.8\%) [25]. There is no doubt about the efficacy of varenicline, which was demonstrated clearly in an experiment with patients who smoked more than 10 cigarettes a day and had previously attempted to quit tobacco using varenicline. The subjects were divided into two groups - patients retreated with varenicline and controls treated with placebo. Twelve weeks after the cessation of smoking, the abstinence rate for varenicline was as high as $45 \%$, whereas that for placebo was only $11.8 \%$ [26].

Varenicline therapy is accompanied by various adverse events. The most frequent is persistent nausea, which occurs up to three times more often in varenicline patients than in those treated with placebo. There have also been reports of changes in behaviour, acts of aggression, suicidal ideation, and suicide attempts during therapy [27].

\section{Cytisine}

Cytisine is an alkaloid obtained, among others, from the common laburnum (Laburnum anagyroides). It is an over-the-counter antinicotinic drug, which is used only in Eastern Europe [28]. Its action resembles that of varenicline. Similarly to this latter medication, cytisine is a partial agonist selective for $\alpha 4 \beta 2$ nicotinic acetylcholine receptors. The efficacy of cytisine has been demonstrated in two studies, in which it was more effective than placebo. In a study by Vinnikov et al., the abstinence rates after 8 weeks of treatment were $10.7 \%$ in the cytisine group and $5.7 \%$ in the placebo group. Interestingly, after 26 weeks, the abstinence rate in the study group remained exactly the same, while in the control group it dropped dramatically to $1.2 \%$ [29]. In West et al.'s study, 740 patients who smoked 10 or more cigarettes a day were divided into two groups. The first group received cytisine and the second took placebo. After 12 months, the efficacy was higher in the cytisine group (8.4\%) than in the control group (2.4\%) [30].

The most common side effect of cytisine therapy is gastrointestinal discomfort. Other adverse events reported more often in the active group than in the placebo group are dizziness and drowsiness. Despite the fact that the mechanism of action of cytisine is similar to that of varenicline, the former has not been observed to produce side effects such as aggressive behaviour or suicidal ideation during over 50 years of its use [30].

\section{E-cigarette}

One of the latest developments in nicotine addiction therapy, which has become very popular and fashionable among quitters, is the electronic cigarette. The popularity of e-cigarettes may be due to the fact that their use most resembles the smoking of regular cigarettes. In 2016, Zhuang et al. published the results of their study, conducted on a group of 2,028 patients, in whom they investigated the impact of short and long-term use of 
e-cigarettes on the chances of quitting. The researchers determined the percentage of subjects using e-cigarettes at baseline and repeated the survey after two years. The study group was divided into three categories: non-users, short-term e-cigarette users, and long-term e-cigarette users. The results showed that long-term e-cigarette users were characterized by significantly higher cessation rates (had been abstinent for at least 3 months) than other groups. Long-term users were also more willing to try to quit: $72 \%$ of them had attempted to stop smoking, which is a much higher rate than that found among non-users (45.5\%) [31]. Other studies have demonstrated that the use of e-cigarettes was associated with higher abstinence rates compared to placebo and similar rates to NRT. It also led to a more than $50 \%$ reduction in the total number of cigarettes smoked $[32,33]$.

\section{Other reports}

In addition to the popular measures mentioned above, attempts are made to treat nicotine addiction with various medications, often the ones used to treat conditions that are seemingly unrelated to nicotinism. An example of such a drug is nortriptyline, a classic tricyclic antidepressant. Although a number of studies have demonstrated its effectiveness in overcoming nicotine addiction [34], nortriptyline, being an antidepressant, exhibits numerous side effects, which include decreased salivary flow (a risk factor of caries), convulsions, and sexual dysfunction. For this reason, nortriptyline is not recommended as a firstline drug in nicotine addiction therapy. There have been attempts to treat nicotinism with other antidepressants, such as venlafaxine or selegiline. Unfortunately, these drugs have not been found to significantly increase the likelihood of smoking cessation. Although venlafaxine seems to work in smokers who smoke less than one packet per day [35], while selegiline may show efficacy in people with particular genetic predispositions [36], these drugs should rather not be recommended to patients who want to quit smoking. A drug that is considered a second-line drug in the treatment of nicotinism in some countries is clonidine, an $\alpha 2$-adrenergic receptor agonist. It reduces the symptoms of nicotine craving and relieves withdrawalrelated anxiety and nervousness. It is recommended especially for people who feel severe anxiety after discontinuing smoking [37]. There are a number of other substances that have been used as potential anti-nicotinic agents, such as glucose tablets, gabapentin, acetylcysteine, levodopa, PPAR- $\gamma$ agonists, or opioid receptor antagonists. For the time being, however, they should be treated as objects of academic inquiry rather than second-line drugs.

\section{Baclofen}

A study of a group of patients addicted to both nicotine and alcohol (and it has to be remembered that as many as a half of alcoholics are also addicted to tobacco) showed that baclofen extended the period of abstinence from both alcohol and nicotine [38]. Similar results have been obtained for topiramate [39].

\section{Combination therapies}

There are many ways which combine pharmacological methods to help patients stop smoking. The best-known and most widely used combination therapies involve the use of various NRTs with varenicline or bupropion.

Patients also readily opt for combination NRT. During such treatment, nicotine patches are used along with another aid such as chewing gum, tablets or inhalers. The action is based on the combination of a long-acting product that maintains a constant concentration of nicotine in the body, with a short-acting form taken as the need arises. The use of a combination of two NRTs is associated with a $30 \%$ greater chance of successful smoking cessation than in the case of monotherapy [40].

Replacement therapy can also be used together with bupropion. Studies have demonstrated that bupropion combined with nicotine patches shows greater efficacy than when it is used on its own. There are few reports on the combined use of bupropion and varenicline. One study showed that such combination therapy was more efficacious after 12 and 26 weeks of treatment than varenicline monotherapy, however, this was not associated with significantly higher long-term abstinence rates at 52 weeks of follow-up [41]. Studies of combination therapy using varenicline and NRT have so far yielded conflicting results, so their simultaneous use is not recommended $[42,43]$. At the current state of knowledge, it seems that the only recommendable combination therapy is the use of two forms of NRT. It is an effective method, and its side effects are not stronger than those of nicotine monotherapy. Due to the limited number of studies, combining NRT with bupropion should be considered with great caution.

\section{Comparison studies of the efficacy of various nicotine addiction treatments}

As can be expected, there exist hundreds of studies which compare the efficacy of various pharmaceutical interventions for nicotine dependence. A comprehensive meta-analysis of this important issue can be found in Cahill et al.'s study published in 2013 (the University of Oxford's Department of Primary Care Health Sciences) 
[44]. This work is an overview of 267 studies investigating a total of 101,804 patients. The aim of the analysis was to show the extent to which drugs commonly used to treat nicotine addiction: varenicline, bupropion and NRTS, increased the likelihood of long-term abstinence (6-month or longer) relative to placebo and how they compared with each other for efficacy. Also, the effectiveness of various NRT forms was compared, and the results of research on less popular agents were collected. Varenicline turned out to be the most effective drug, while bupropion and NRT were almost equally effective. Most importantly, the metaanalysis indicated that all three types of intervention could be used effectively to help quitters in their cessation attempts.

A next part of the meta-analysis compared the efficacy of various forms of NRT. It was shown that while the individual NRT products were characterized by similar efficacy, combination NRT significantly increased the effectiveness of treatment. The efficacy of combination NRT in relation to placebo was as high as 2.73 , which was comparable with the effectiveness of varenicline. However, it should be taken into account that this value is the average of only two studies, which means it cannot be legitimately compared to the results of studies on varenicline, bupropion or general results for NRT. It is also worth mentioning the results of a study by Kautiainen et al. on the effectiveness of re-treatment with varenicline, bupropion and NRT in cases when the first attempt to overcome nicotine addiction had proven ineffective. The study was partly based on the authors' own research and partly on data from scientific literature. It was found that successive attempts to break with the addiction using the same substance significantly increased permanent abstinence rates. Once again, the superiority of varenicline over other drugs was demonstrated. An interesting observation was that patients who were treated with varenicline for the first time stood only a slightly lower chance of permanent abstinence than those retreated with bupropion and NRT. It is worth emphasizing that most smokers fail to permanently break with smoking at the first attempt. Relapses may occur even after a year of abstinence. The likelihood of relapse, however, decreases with time. The average risk of returning to smoking is $6 \%$ per annum two to five years after quitting [45], 2\% - five to ten years after quitting [46], and $1 \%$ for ex-smokers who have abstained from smoking for more than 10 years. High efficacy of varenicline as a cessation aid compared to bupropion is confirmed by a placebo-controlled study conducted by Jorenby et al. and Gonzales et al. [54, 55].

\section{Gender-related efficacy of pharmacotherapy for nicotine dependence}

Numerous scientific studies provide evidence that pharmaceutical interventions increase patients' chances of stopping smoking. However, one can ask the question of what determines the effectiveness of a particular drug for a particular patient. Factors such as gender, age or race often influence the action of medications. The relationship between the effectiveness of various forms of nicotine dependence treatment and gender was described by Smith et al. in a meta-analysis published in 2016 [47]. This work reviewed the results of 28 different studies that met the authors' criteria of therapeutic efficacy. The study compared pharmacological interventions for smoking cessation that were most popular in Western European countries: varenicline, bupropion and transdermal nicotine (NRT). The analysis showed that the effectiveness of these medications differed between men and women. Although varenicline was the most effective, and NRT the least effective, intervention in both groups of patients, differences in efficacy were distinct for the two sexes. While for men, there were only slight differences in the efficacy of varenicline over bupropion, and bupropion over NRT, in women, the quit rates for varenicline were over 50 percent higher than for the other forms of therapy (whose efficacies were very similar in this group). Bearing in mind that varenicline therapy is significantly more expensive than bupropion therapy, one may question the sense of using varenicline in men, but it certainly should be considered the most effective option in the treatment of addicted women.

\section{Varenicline and suicide}

Taking into account the results of the studies presented earlier, there is no doubt that varenicline therapy is currently the most effective pharmaceutical intervention for the treatment of nicotinism. However, the question remains whether it is safe enough to be offered to every patient. It seems risky to administer a drug that can cause suicidal ideation or changes in behaviour. Tadrous et al. reviewed reports of suicides and auto-aggressive behaviour during varenicline therapy and bupropion treatment. The results of their work published in 2016 seem very optimistic. A similar study had already been conducted earlier [48], but in a smaller cohort of patients. It turns out that varenicline users are not significantly more likely to attempt suicide and engage in auto-aggressive behaviour than patients treated with bupropion [49], which is considered not to cause such side effects [50]. 


\section{Conclusions}

All commonly used pharmaceutical agents used in the treatment of nicotinism (NRTs, bupropion, varenicline, cytisine) show significantly higher efficacy than placebo.

Varenicline is more effective than bupropion and NRTs. The effectiveness of NRT can be enhanced to a level comparable to varenicline when two forms of this therapy are used simultaneously.

Contrary to previous reports, it seems that varenicline does not increase auto-aggressive behaviour or the risk of suicide.

The efficacy of antinicotinic drugs depends on the patient's gender. For both sexes, the most effective substance is varenicline. It is somewhat more effective in women, whereas NRT and bupropion show greater therapeutic potential in men.

Cytisine, which is available in Eastern Europe, is the least-known smoking cessation agent; so far, there have been no studies comparing its effectiveness to that of other popular antinicotinic drugs. Two very important factors affecting the chances of successful treatment of nicotine dependence are the patient's motivation to break with the addiction and good contact and communication between the doctor and the patient. Patients are motivated to fight the addiction when they are in a life-threatening condition, with acute coronary syndrome being one of the most frequent causes of quitting. Many patients who face the risk of dying attach great importance to modifiable risk factors for vascular diseases, such as tobacco smoking.

Table 1. Comparison of some nicotine addiction therapy methods

\begin{tabular}{|l|l|l|l|l|}
\hline Type of therapy & NRT & Bupropione & Warenicline & Citisine \\
\hline $\begin{array}{l}\text { efficiency against } \\
\text { placebo }\end{array}$ & higher efficiency & higher efficiency & higher efficiency & higher efficiency \\
\hline advantages & different characters & less weight gain & $\begin{array}{l}\text { decreased severity of } \\
\text { withdrawal symptoms }\end{array}$ & $\begin{array}{l}\text { no aggressive behaviour } \\
\text { was reported }\end{array}$ \\
\hline disadvantages & $\begin{array}{l}\text { delivering nicotine } \\
\text { to the body }\end{array}$ & the risk of seizures & often persistent nausea & $\begin{array}{l}\text { often gastrointestinal } \\
\text { discomfort }\end{array}$ \\
\hline
\end{tabular}

\section{Wstęp}

Palenie papierosów jest powszechnym problemem w Polsce, aż 24\% Polaków uzależnionych jest od nikotyny [1]. Szacunkowo 6 milionów ludzi na świecie umiera rocznie $\mathrm{z}$ powodu chorób, które są $\mathrm{w}$ ścisłym związku z nałogiem - takich jak nowotwory, choroby układu krążenia, metaboliczne lub płuc. W samym XX wieku odnotowano niemal 100 milionów zgonów spowodowanych paleniem tytoniu $[2,3]$. W trakcie inhalacji papierosem uwalnianych jest około 7000 związków chemicznych, spośród których znaczna ilość jest kancerogenna [3]. W Stanach Zjednoczonych wykazano związek palenia papierosów z określoną liczbą zejść śmiertelnych w poszczególnych zespołach chorobowych. Aż 87\% zgonów wśród nowotworów płuc, 61\% zgonów wśród chorób płuc i 32\% zgonów wśród epizodów choroby wieńcowej było powiązanych z paleniem. Mimo wysokiej świadomości o szkodliwości tytoniu wielu uzależnionych nie jest w stanie definitywnie rzucić palenia. Trudność w zwyciężeniu nałogu jest spowodowana złożonym mechanizmem uzależnienia. Inhalacja dymem tytoniowym powoduje bardzo szybki wzrost stężenia nikotyny w osoczu krwi. Prowadzi to do stymulacji neuronalnych acetylocholinergicznych receptorów nikotynowych $\alpha 4 \beta 2$. Powoduje to uwolnienie dopaminy do jądra półleżącego - elementu ośrodka nagrody. Regularnie zażywana nikotyna prowadzi do deregulacji podstawowego wydzielania dopaminy, co przy nagłym zaprzestaniu dostarczania substancji skutkuje pojawieniem się objawów zespołu abstynencyjnego, wywołanego spadkiem stężenia dopaminy w organizmie. Wielokrotne powtarzanie i kojarzenie czynności palenia papierosów z przyjemnością rozwija kolejny rodzaj uzależnienia - uzależnienie psychiczne [3]. Należy podkreślić, że ogromne znaczenie $\mathrm{w}$ trudnym procesie wychodzenia $\mathrm{z}$ nałogu ma motywacja pacjenta do porzucenia palenia. Wzmacnianie tej motywacji jest jednym z najistotniejszych zadań lekarzy i terapeutów uzależnień. Można zaobserwować, że dla wielu pacjentów przyczynkiem do decyzji o porzuceniu nałogu staje się zagrażająca życiu nagła choroba, szczególnie często jest ostry zespół wieńcowy. Prawidłowo budowany i podtrzymywany kontakt terapeutyczny stanowi jeden z fundamentów współpracy z osoba uzależnioną od nikotyny i może w dużym stopniu decydować o powodzeniu terapii.

\section{Omówienie danych z literatury}

Jak wynika ze statystyk TNS Polska, z roku na rok rośnie liczba palaczy podejmujących próbę walki z nałogiem [4]. Od września 2014 do 2015 próbę odstawienia tytoniu podjęło w Polsce $25 \%$ palących kobiet i 31\% palących mężczyzn. Skuteczność w obu grupach była porównywalna i wynosiła około 36\%. 
Wielu uzależnionym nie udaje się rozstać z papierosami wyłącznie przy użyciu silnej woli i uciekają się do metod wspomagających, niekiedy mających oparcie w nauce, niekiedy stanowiących przykłady medycyny alternatywnej. Do technik o udowodnionej skuteczności należy przede wszystkich farmakoterapia. Popularność zyskuje ostatnio także psychoterapia behawioralnokognitywna, szczególnie skuteczna gdy jest to specjalistyczna terapia dostosowana do rasy, kultury, czy też religii pacjenta [4].

Pewnego rodzaju ciekawostką są próby leczenia za pomocą biorezonansu. Terapię tą zaczęto stosować w Niemczech w latach $70 \mathrm{XX}$ wieku. Aparat do biorezonansu składa się $\mathrm{z}$ komputera i czterech elektrod - dwóch trzymanych w dłoniach i dwóch dotykających stóp. Elektrody odbierają naturalne fale elektromagnetyczne o niskiej częstotliwości emitowane przez ludzki organizm. Następnie komputer wzmacnia odbierane sygnały, niekiedy odwraca ich fazę i wysyła $\mathrm{z}$ powrotem do organizmu, by nakładały się z naturalnym polem elektromagnetycznym człowieka [5]. Według badaczy zajmujących się tym rodzajem terapii wystarczą 2-3 sesje biorezonansu, by skutecznie rzucić palenie. Mimo iż zabieg ten uważany jest często za pseudonaukowy, istnieją badania potwierdzające jego skuteczność w rzucaniu palenia. W pracy Aylin Pihtilia i wsp. wykazano, iż w grupie badanej, leczonej biorezonansem skuteczne rzucenie palenia udało się znacznie większemu odsetkowi pacjentów niż w grupie kontrolnej, gdzie biorezonans był jedynie symulowany. Co ważne, skuteczność odstawienia tytoniu była badana po tygodniu, dwóch tygodniach, miesiącu i roku od wykonania zabiegu i za każdym razem w grupie badanej abstynencję zachowywało więcej osób niż w grupie kontrolnej [6].

W naszym artykule skupimy się jednak przede wszystkim na farmakoterapii. Początki tej ścieżki leczenia sięgają lat 30. XX wieku, gdy przeprowadzono próby leczenia lobeliną [7], będącą swego rodzaju substytutem nikotyny. Od tamtego czasu możemy zaobserwować w farmakologii uzależnień pewien postęp i dziś znamy więcej substancji wspomagających walkę $\mathrm{z}$ nałogiem. Działają one poprzez różne mechanizmy, występują w licznych formach i dawkach. Najważniejsze z nich postaramy się przybliżyć w kolejnej części artykułu.

\section{NRT - Nikotynowa terapia zastępcza}

Dobrze poznanym sposobem wspomagania wychodzenia z nałogu palenia papierosów od wielu lat jest nikotynowa terapia zastępcza. Polega ona na dostarczeniu nikotyny do organizmu w sposób mniej szkodliwy niż poprzez dym tytoniowy. W konsekwencji zmniejsza się potrzeba palenia papierosów, co prowadzić ma do całkowitego zerwania z nałogiem. Badania kliniczne wykazały, że stosowanie NRT wiąże się ze zwiększoną o 50-70\% szansą na utrzymanie abstynencji od palenia tytoniu w porównaniu z placebo [8]. Istnieje wiele metod przyjmowania terapii zastępczej, są to gumy do żucia z nikotyną, plastry nikotynowe, pastylki do ssania, listki rozpuszczalne w jamie ustnej czy inhalatory. Wybór metody zależy od osobistych preferencji użytkownika. Poszczególne formy NRT wykazują porównywalną skuteczność [9]. Zaletą gumy do żucia oraz tabletek do ssania jest zastąpienie czynności jaką jest palenie papierosa, poprzez żucie gumy czy ssanie tabletki. Może to pomóc zastąpić rytuał „wyjścia na papierosa”. Ilość nikotyny zawarta $\mathrm{w}$ gumie lub tabletce jest niewielka, przez co konieczne jest wielokrotne ich stosowanie w ciągu dnia. Wadą tych metod jest występowanie czkawki, ślinotoku czy podrażnień w jamie ustnej [10]. Plastry nikotynowe są metodą o udowodnionym bezpieczeństwie oraz skuteczności [11]. Ich niewątpliwą zaletą jest łatwość $\mathrm{w}$ stosowaniu. Wymagają codziennego naklejenia na skórę plastra, z którego nikotyna uwalniana jest w sposób ciągły, wolniejszy niż w przypadku innych form NRT [12]. Plastry dostępne są w zróżnicowanych dawkach, utrzymuje się je na skórze przez 16 lub 24 godziny. Efekty uboczne obejmują reakcje skórne w miejscu przyklejenia oraz zaburzenia snu $\mathrm{w}$ przypadku użycia wersji 24-godzinnych [13]. Kontrowersyjna pozostaje kwestia stosowania NRT u kobiet $\mathrm{w}$ ciąży. Przeprowadzone badania wykazały, iż przyjmowanie terapii zastępczej przez ciężarną jest uzasadnione tylko wtedy, gdy kobieta nie jest w stanie samodzielnie zaprzestać palić tytoniu. NRT ma za zadanie ograniczyć narażenie płodu na inne substancje występujące $\mathrm{w}$ dymie papierosowym oraz ułatwić całkowite zerwanie $\mathrm{z}$ nałogiem [14]. Badania nad poziomem nikotyny u palących ciężarnych wykazały o ok. 30\% mniejsze stężenie tego związku po zastąpieniu papierosów przez NRT. Ponadto wykazano, iż korzystanie $\mathrm{z}$ terapii zastępczych zmniejsza ryzyko niskiej masy urodzeniowej dziecka oraz porodów przedwczesnych, w porównaniu do kobiet kontynuujących palenie w ciąży [15]. Najskuteczniejszą metodą ochrony płodu pozostaje jednak całkowite zaprzestanie palenia tytoniu bez przyjmowania nikotyny w żadnej innej formie.

Badania nad grupą uzależnionych nastolatków w wieku 12-18 lat, wykazały nieskuteczność NRT w tej grupie wiekowej. Po 12 miesiącach od rozpoczęcia zbierania danych wśród tych pacjentów wykazano zbliżoną skuteczność NRT do placebo [16].

Przyjmowanie nikotyny $\mathrm{w}$ formie leku niesie za sobą ryzyko działań niepożądanych, wynikających $\mathrm{z}$ osiągnięcia wysokiego poziomu nikotyny we krwi. Nikotyna w dawkach toksycznych może w skrajnych przypadkach prowadzić do śmierci z powodu depresji 
ośrodka oddechowego. Dowiedziono jednak na dużej grupie badanej, że przestrzeganie zalecanych dawek NRT nie niesie za sobą ryzyka przedawkowania [17].

\section{Bupropion}

Spośród środków mających zastosowanie w leczeniu uzależnienia od nikotyny można wyróżnić leki, które pierwotnie były stosowane $\mathrm{w}$ leczeniu zaburzeń depresyjnych. Najpowszechniej stosowanym specyfikiem $\mathrm{z}$ tej grupy jest bupropion. Jest to selektywny inhibitor wychwytu zwrotnego dopaminy i noradrenaliny. Lek ten jest jednym z najczęściej stosowanych w farmakoterapii depresji w Stanach Zjednoczonych. Jednocześnie dostrzeżono jego pozytywny wpływ na osoby próbujące zerwać z nałogiem palenia papierosów. Mechanizm działania pozostaje $\mathrm{w}$ tym przypadku nieznany, jednak badania wskazują jednoznacznie na skuteczność bupropionu, która jest porównywalna ze skutecznością NRT [18]. Stosowanie bupropionu powoduje jednak wyższy odsetek utrzymania długoterminowej abstynencji oraz mniejszy wzrost masy ciała wywołany zaprzestaniem palenia [19,20]. Wykazano, że skuteczność leczenia jest niezależna od tego, czy u pacjenta występowały lub występują zaburzenia depresyjne. Terapia powinna trwać minimum 7 tygodni, może jednak trwać nawet do roku. Najpoważniejszym efektem ubocznym stosowania leku jest zwiększone ryzyko wystąpienia napadów drgawkowych, dlatego nie można go stosować u osób, u których występują czynniki ryzyka takie jak padaczka, urazy głowy, stosowanie leków obniżających próg pobudliwości drgawkowej, cukrzyca czy uzależnienie od alkoholu. Inne działania niepożądane obejmują suchość w ustach, bezsenność, ból głowy, suchość w jamie ustnej oraz zaburzenia ze strony przewodu pokarmowego. Poważne dolegliwości występują jednak rzadko, z tego powodu bupropion jest uważany za lek bezpieczny [21]. Badania nad stosowaniem bupropionu w ciąży wykazały, że nie ma on negatywnego wpływu na procesy metaboliczne płodu lub matki, jednak istnieją doniesienia o zwiększonym ryzyku występowania wad serca u dziecka [22]. Istnieje zbyt mało doniesień pozwalających odnieść się do stosowania leku w trakcie ciąży, w związku $\mathrm{z}$ tym podawanie leku jest wskazane tylko w leczeniu ciężkich epizodów depresyjnych.

\section{Wareniklina}

Niewątpliwie warto zwrócić uwagę na wareniklinę, która według badań jest jednym z najskuteczniejszych leków w stosowanych jako farmakoterapia uzależnienia od nikotyny, ponadto rezultaty wielu badań pokazują, że specyficznie hamuje ona poszukiwanie alkoholu u zwierząt laboratoryjnych [23,51,52,53]. Mimo swojej wysokiej skuteczności nie jest aż tak popularna jak NRT czy bupropion. Wareniklina jest selektywnym, częściowym agonistą acetylocholinergicznych receptorów nikotynowych $\alpha 4 \beta 2$. Substancja ta ma wyższe powinowactwo do tych receptorów niż nikotyna. Pobudzając je powoduje wzrost wydzielania dopaminy, lecz w niższym stopniu niż w przypadku palenia papierosów, co powoduje zmniejszenie objawów abstynencyjnych [24]. Leczenie najkorzystniej jest rozpocząć na tydzień przed wcześniej zaplanowaną datą rzucenia papierosów [25]. Okres ten pozwoli na wysycenie organizmu lekiem w mniejszej dawce, co powoduje długoterminowe zmniejszenie objawów ubocznych - głównie nudności. W badaniach Petera Hajek'a i wsp. spróbowano jednak wydłużyć okres wysycania organizmu z jednego do czterech tygodni. Po okresie dwunastu tygodni od momentu zaprzestania palenia abstynencja $\mathrm{w}$ grupie eksperymentalnej była znacznie wyższa $(47,2 \%)$ niż w grupie pacjentów leczonych według oficjalnych zaleceń $(20,8 \%)$ [25]. Nie ma wątpliwości co do skuteczności terapii za pomocą warenikliny. Przebadano pacjentów palących więcej niż 10 papierosów dziennie, którzy wcześniej podjęli próbę rzucenia tytoniu przy pomocy warenikliny i podzielono ich na dwie grupy - badawczą z warenikliną i kontrolną z placebo. Po dwunastu tygodniach od zaprzestania palenia papierosów odsetek abstynentów w grupie badawczej wynosił aż 45\%, podczas gdy wśród pacjentów z podanym placebo jedynie $11,8 \%$ [26].

Terapii za pomocą warenikliny towarzyszą rozmaite skutki uboczne. Najczęściej występują uporczywe nudności, które u pacjentów zażywających lek występowały aż 3 razy częściej niż u grupy z placebo. Odnotowano przypadki, w których podczas terapii dochodziło do zmiany zachowania, aktów agresji lub myśli i prób samobójczych [27].

\section{Cytyzyna}

Cytyzyna jest alkaloidem pozyskiwanym między innymi ze złotokapu zwyczajnego (Laburnum anagyroides). Tę substancję stosuje się w celu terapii nikotynizmu tylko w Europie Wschodniej i jest tam dostępna bez recepty [28]. Swoim działaniem przypomina wareniklinę. Podobnie jak ona jest częściowym agonistą acetylocholinergicznych receptorów nikotynowych $\alpha 4 \beta 2$. Efektywność cytyzyny dowiedziono w dwóch badaniach, w których okazała się skuteczniejsza od placebo. W badaniach Denisa Vinnikova i wsp. udokumentowano odsetek abstynencji po 8 tygodniach na poziomie 10,7\%, podczas gdy w grupie placebo wynosił 5,7\%. Co ciekawe po 26 tygodniach odsetek abstynencji w grupie badanej 
pozostał dokładnie na tym samym poziomie, podczas gdy w grupie placebo wyraźnie spadł osiągając poziom 1,2\% [29]. W pracy Roberta Westa i wsp. podzielono na dwie grupy 740 pacjentów, którzy palili 10 lub więcej papierosów dziennie. Pierwsza grupa przyjmowała cytyzynę, druga placebo. Po 12 miesiącach odnotowano wyższą skuteczność w grupie leczonej cytyzyną $(8,4 \%)$ w porównaniu do grupy kontrolnej (2,4\%) [30].

W trakcie terapii cy tyzyną najczęściej występującymi skutkami ubocznymi są dolegliwości żołądkowo-jelitowe. Częściej niż w grupie placebo występują również zaburzenia takie jak zawroty głowy lub senność. Mimo podobnego do warenikliny mechanizmu działania przez ponad 50 lat stosowania nie zaobserwowano skutków ubocznych takich jak agresywne zachowanie lub myśli samobójcze [30].

\section{E-papieros}

Jedną z najnowszych, bardzo popularnych i modnych metod wspomagających walkę $\mathrm{z}$ uzależnieniem od nikotyny są $\mathrm{z}$ pewnością elektroniczne papierosy. Popularność e-papierosów może wynikać z tego, że zażywanie w ten sposób nikotyny najbardziej przypomina palenie klasycznych papierosów. W 2016 roku ukazały się wyniki badań prowadzonych przez Yue-Lin Zhuang i wsp. prowadzonych na grupie 2028 pacjentów uzależnionych od nikotyny, obrazujące wpływ krótkoi długoterminowego stosowania e-papierosów na szansę zerwania z nałogiem. Na początku testu określono jaki procent badanych używa e-papierosa, badanie to powtórzono po 2 latach. Grupa badana podzielona została na 3 kategorie: osoby nie używające e-papierosów, osoby używające e-papierosów krótkoterminowo oraz te osoby, które używały e-papierosów w długim okresie czasu. Wyniki pokazały, że osoby stosujące e-papieros długoterminowo charakteryzowały się znacząco większym odsetkiem zaprzestania palenia na co najmniej 3 miesiące. Długoterminowi użytkownicy chętniej podejmowali również próby rzucania nałogu, 72\% z nich podjęło próbę zaprzestania palenia, co jest wartością znacznie wyższą od grupy badanych nie stosujących tej metody $(45,5 \%)$ [31]. W innych badaniach wykazano, że używanie elektronicznych papierosów prowadziło do wyższego odsetka abstynencji w porównaniu z placebo, podobnego odsetka jak w przypadku stosowania NRT, oraz zmniejszenia ogólnej ilości wypalanych papierosów o ponad $50 \%[32,33]$.

\section{Inne doniesienia}

Poza popularnymi, wymienionymi wcześniej środkami, podejmuje się próby leczenia nałogu nikotynowego różnymi lekami, często używanymi w leczeniu pozornie niezwiązanych z nikotynizmem schorzeń. Przykładem takiego leku jest nortryptylina, klasyczny, trójpierścieniowy lek przeciwdepresyjny. Choć szereg badań wykazał jego skuteczność w pokonywaniu uzależnienia od nikotyny [34] jako klasyczny lek przeciwdepresyjny wykazuje on liczne działania niepożądane, do których należy predysponujący do próchnicy spadek wydzielania śliny, drgawki, czy też zaburzenia funkcji seksualnych. Z tego powodu trudno polecać nortryptylinę jako lek pierwszego rzutu w terapii uzależnienia. W leczeniu nikotynizmu próbowano wykorzystać też inne leki przeciwdepresyjne, takie jak wenlafaksyna, czy selegilina. Niestety nie wykazano, by leki te istotnie zwiększały prawdopodobieństwo porzucenia nałogu. Wenlafaksyna wydaje się co prawda działać u palaczy wypalających mniej niż jedną paczkę dziennie [35], zaś selegilina może wykazać skuteczność u osób ze szczególnymi predyspozycjami genetycznymi [36], jednak leki te raczej nie powinny być proponowane pacjentom chcącym zaprzestać palenia tytoniu. Lekiem, który w niektórych krajach jest uznany za lek drugiego rzutu w leczeniu uzależnienia jest klonidyna, agonista receptorów $\alpha 2$-adrenergicznych. Zmniejsza ona objawy głodu nikotynowego, łagodzi związany z odstawieniem niepokój i nerwowość. Zalecana jest szczególnie osobom odczuwającym silny niepokój po odstawieniu papierosów [37]. Istnieje szereg innych substancji, które próbowano stosować w leczeniu nikotynizmu jak glukoza w tabletkach, gabapentyna, acetylocysteina, lewodopa, agoniści PPAR- $\gamma$ lub antagoniści receptorów opioidowych. Póki co należy je traktować jednak bardziej jako obiekty akademickich rozważań niż leki drugiego rzutu.

\section{Baklofen}

W grupie pacjentów uzależnionych jednocześnie od nikotyny i alkoholu (a należy do niej nawet połowa alkoholików) zauważono, iż baklofen wydłuża okres abstynencji zarówno od alkoholu jak i nikotyny [38]. Podobne rezultaty zaobserwowano w odniesieniu do topiramatu [39].

\section{Terapie złożone}

Istnieje wiele sposobów łączenia poszczególnych metod farmakologicznych pomocnych w rzucaniu palenia. Najlepiej poznane i najchętniej wykorzystywane połączenia zakładają używanie różnych form NRT oraz ich kombinacje $\mathrm{z}$ warenikliną lub bupropionem. Pacjenci chętnie sięgają po NRT stosowaną w dwóch formach. Wykorzystywane są wtedy plastry nikotynowe wraz z inną metodą - gumami, tabletkami czy inhalatorami. 
Istotą działania jest tutaj połączenie formy długo działającej, utrzymującej stałe stężenie nikotyny $\mathrm{w}$ organizmie, z formą krótko działającą przyjmowaną $\mathrm{w}$ razie potrzeby. Stosowanie połączenia dwóch terapii NRT wiąże się z około $30 \%$ większą szansą na całkowite zerwanie z nałogiem niż w przypadku monoterapii [40]. Terapię zastępczą można stosować również łącznie z bupropionem. Jego połączenie z plastrami nikotynowymi w badaniach wykazało wyższą skuteczność niż zażywanie samego bupropionu. Istnieje niewiele doniesień dotyczących stosowania połączenia bupropionu z warenikliną. Badania te wykazały większą skuteczność terapii złożonej po 12 oraz 26 tygodniu leczenia, nie wiązało się to jednak ze znacząco wyższym odsetkiem długotrwałej abstynencji w 52 tygodniu [41]. Badania na temat łączenia warenikliny z NRT przyniosły dotychczas sprzeczne rezultaty, w związku z czym to zestawienie nie jest zalecane $[42,43]$. Przy obecnym stanie wiedzy wydaje się, że stosowanie terapii złożonej powinno ograniczyć się do przyjmowania dwóch form NRT. Jest to połączenie skuteczne, przy czym nie jest obarczone wystąpieniem silniejszych efektów ubocznych niż w przypadku monoterapii nikotynowej. Ze względu na ograniczoną ilość badań, do łączenia NRT z bupropionem należy podchodzić z dużą rezerwą.

Badania porównujące skuteczność różnych metod uzależnienia od nikotyny

Jak można się spodziewać, powstały setki opracowań porównujących skuteczność różnych form farmakoterapii uzależnienia od nikotyny. Obszerną analizę tego ważnego zagadnienia wiedzy znajdziemy w opublikowanej w 2013 roku pracy Kate Cahill i wsp. (Department of Primary Care Health Sciences uniwersytetu w Oxfordzie) [44]. W opracowaniu wzięto pod uwagę 267 prac, w których badaniom poddano $\mathrm{w}$ sumie aż 101804 pacjentów. Celem zespołu badawczego było wykazanie w jakim stopniu powszechnie stosowane w leczeniu uzależnienia od nikotyny leki: wareniklina, bupropion i NRT zwiększają prawdopodobieństwo utrzymania długoterminowej (co najmniej 6-miesięcznej) abstynencji w stosunku do placebo i siebie nawzajem. Porównano także skuteczność różnych form NRT, oraz zebrano wyniki prac dotyczących mniej popularnych substancji. Lekiem o zdecydowanie największej efektywności okazała się wareniklina, zaś bupropion i NRT cechują się niemal jednakową skutecznością. Co najważniejsze, badania wskazują na to, że wszystkie 3 leki mogą w efektywny sposób przyczynić się do skutecznej walki z nałogiem.

W kolejnej części metaanalizy porównywano skuteczność różnych form NRT. Wykazano, że o ile poszczególne formy podawania nikotyny cechuje podobna skuteczność, o tyle efektywność kuracji wzrasta znacząco przy zastosowaniu leczenia skojarzonego z użyciem kilku form NRT. Efektywność takiego leczenia w stosunku do placebo wynosi aż 2,73 co jest wartością porównywalną ze skutecznością warenikliny. Należy jednakże wziąć pod uwagę, iż wartość ta jest średnią wyciągniętą z zaledwie 2 opracowań i trudno porównywać ją do wyników badań dotyczących warenikliny, bupropionu czy ogólnych wyników NRT. Warto też nawiązać do wyników pracy Kirsi Kautiainen i wsp. dotyczącej skuteczności ponownego leczenia warenikliną, bupropionem oraz NRT w przypadku gdy pierwsza próba pokonania uzależnienia okazała się nieskuteczna. Opracowanie częściowo bazowało na własnych badaniach, częściowo na literaturze naukowej. Dowiedziono, iż kolejne próby zerwania z nałogiem przy pomocy tej samej substancji znacząco zwiększają prawdopodobieństwo uzyskania trwałej abstynencji. Kolejny raz ukazano też przewagę warenikliny nad innymi lekami. Ciekawym spostrzeżeniem może być to, że już pojedyncza próba odstawienia tytoniu wsparta warenikliną daje niewiele mniejsze szanse osiągnięcie trwałej abstynencji niż dwukrotne leczenie bupropionem i NRT. Warto podkreślić bardzo istotny fakt - większości palaczy nie udaje się trwale zerwać z paleniem przy pierwszej próbie. Nawet po roku abstynencji zdarzają się powroty do nałogu. Prawdopodobieństwo ponownego sięgnięcia po papierosa zmniejsza się jednak z czasem. Od 2 do 5 roku ryzyko wynosi 6\% rocznie [45], od 5 do 10 roku $2 \%$ [46], a gdy abstynencja trwa już ponad 10 lat - średnio 1\% byłych palaczy powraca do nałogu. Wysoką skuteczność warenikliny jako leku wspomagającego rzucanie palenia w porównaniu do bupropionu potwierdzają kontrolowane placebo badania Jorenby i wsp. oraz Gonzales i wsp. $[54,55]$.

\section{Skuteczność farmakoterapii w zależności od płci}

Dzięki licznym badaniom naukowym wiemy, że farmakoterapia z całą pewnością zwiększa szanse na zaprzestanie palenia. Można jednak postawić sobie pytanie, od czego zależy skuteczność danego leku w przypadku konkretnego pacjenta. Często wpływ na działanie leków mają czynniki takie jak płeć, wiek czy rasa osoby zażywającej substancję. Zależność efektywności różnych form leczenia uzależnienia od nikotyny od płci została opisana przez doktora Philipa Smitha i wsp. w wydanej w roku 2016 metaanalizie [47]. W pracy uwzględniono wyniki 28 różnych badań spełniających wyznaczone przez zespół kryteria skuteczności terapeutycznej. Analizie poddano najpopularniejsze w krajach zachodnich substancje wspomagające zaprzestanie palenia - wareniklinę, 
bupropion i NRT (w formie przezskórnej). Po szczegółowej interpretacji i opracowaniu wszystkich wyników okazało się, iż skuteczność wymienionych leków u mężczyzn różni się od ich efektywności w grupie kobiet. Jak widać, w obu grupach pacjentów wareniklina jest substancją najskuteczniejszą, zaś NRT najmniej skuteczną, jednak różnice w efektywności są dla obu płci odmienne. 0 ile wśród mężczyzn przewaga warenikliny nad bupropionem i bupropionu nad NRT jest niewielka, o tyle w grupie kobiet skuteczność warenikliny jest większa o ponad 50 punktów procentowych od skuteczności pozostałych form terapii, których efektywność jest z kolei w tej grupie bardzo podobna. Mając na uwadze, że terapia warenikliną jest znacznie droższa niż bupropionem, można poddać w wątpliwość sensowność stosowania warenikliny u mężczyzn, zaś z całą pewnością należy ją uznać za najbardziej efektywną opcję w leczeniu uzależnionych kobiet.

\section{Wareniklina a samobójstwo}

Biorąc pod uwagę wyniki prezentowanych wcześniej badań, nie ma wątpliwości, że terapia za pomocą warenikliny jest obecnie najskuteczniejszą metodą farmakoterapii nikotynizmu. Pozostaje jednak pytanie czy jest ona na tyle bezpieczna, aby móc zaproponować ją każdemu pacjentowi? Ryzykowne wydaje się podawanie leku, który może wywoływać myśli samobójcze lub zmiany zachowania. Tadrous i wsp. postanowili zweryfikować doniesienia dotyczące samobójstw i zachowań autoagresywnych porównując terapię warenikliną do leczenia bupropionem. Opublikowane w 2016 roku wyniki tej pracy wydają się napawać optymizmem. Podobne badania były już wcześniej prowadzone [48], jednak dotyczyły one mniejszych grup pacjentów. Okazuje się, że próby samobójcze lub zachowania autoagresywne nie występują istotnie częściej przy stosowaniu warenikliny niż przy terapii bupropionem [49], który uznany jest za lek pozbawiony takich skutków ubocznych [50].

\section{Wnioski}

Spośród powszechnie stosowanych metod farmakoterapii nikotynizmu (NRT, bupropion, wareniklina, cytyzyna) wszystkie wykazują efektywność istotnie większą niż placebo. Wareniklina wykazuje wyższą skuteczność niż bupropion i poszczególne formy NRT. Przyjmowanie NRT w dwóch formach równocześnie powoduje wzrost skuteczności tej metody do poziomu porównywalnego z warenikliną.

Wbrew wcześniejszym doniesieniom, wydaje się, że wareniklina nie wzmaga zachowań autoagresywnych i nie zwiększa ryzyka samobójstwa.

Skuteczność leków zależy od płci pacjenta. Dla obu płci substancją o największej efektywności jest wareniklina. Jest ona nieco skuteczniejsza w grupie kobiet, podczas gdy NRT i bupropion wykazują większy potencjał terapeutyczny u mężczyzn.

Dostępna w Europie Wschodniej cytyzyna jest najmniej poznaną substancją, badania porównujące jej efektywność z innymi popularnymi środkami nie są póki co dostępne. Bardzo istotnymi czynnikami wpływającymi na szanse powodzenia terapii uzależnienia od nikotyny są motywacja pacjenta do zerwania z nałogiem i prawidłowy, oparty na dialogu kontakt terapeutyczny. Często silnym bodźcem do walki $\mathrm{z}$ nałogiem jest przeżycie stanu zagrożenia życia w postaci ostrego zespołu wieńcowego. Wiele osób przywiązuje w takiej sytuacji dużą wagę do modyfikowalnych czynników ryzyka schorzeń naczyniowych, do których należy między innymi palenie tytoniu.

Tabela 1. Porównanie niektórych metod terapii uzależnienia od nikotyny

\begin{tabular}{|c|c|c|c|c|}
\hline Rodzaj terapii & $N R T$ & Bupropion & Wareniklina & Cytyzyna \\
\hline $\begin{array}{l}\text { skuteczność } \\
\text { względem placebo }\end{array}$ & wyższa & wyższa & wyższa & wyższa \\
\hline zalety & różne postacie & $\begin{array}{l}\text { mniejszy wzrost } \\
\text { masy ciała }\end{array}$ & $\begin{array}{l}\text { zmniejszenie } \\
\text { nasilenia objawów } \\
\text { abstynencyjnych }\end{array}$ & $\begin{array}{l}\text { nie odnotowano } \\
\text { zachowań agresywnych }\end{array}$ \\
\hline wady & $\begin{array}{l}\text { dostarczanie nikotyny } \\
\text { do organizmu }\end{array}$ & $\begin{array}{l}\text { ryzyko napadów } \\
\text { drgawkowych }\end{array}$ & $\begin{array}{l}\text { często uporczywe } \\
\text { nudności }\end{array}$ & $\begin{array}{l}\text { często dolegliwości } \\
\text { żołądkowo-jelitowe }\end{array}$ \\
\hline
\end{tabular}

\section{Conflict of interest}

The authors have declared no conflict of interest.

\section{References:}

1. TNS Polska Ogólnopolskie badanie ankietowe na temat postaw wobec palenia ty toniu, Sierpień 2015.

2. World Health Organization. WHO REPORT ON THE GLOBAL
TOBACCO EPIDEMIC: Raising taxes on tobacco, 2015.

3. Henningfield JE, Keenan RM. Nicotine delivery kinetics and abuse liability. J. Consult. Clin. Psychol. 1993; 61(5): 743-750.

4. Hooper MW, Antoni MH, Okuyemi K, Dietz NA, Resnicow K. Randomized Controlled Trial of Group-Based Culturally Specific Cognitive Behavioral Therapy among African American Smokers. Nicotine Tob Res. 2017; 19(3): 333-341.

5. Morell F. MORA-Therapie - patienteneigene und Farblichtschwingungen. Heidelberg, Haug. German, 1987. 
6. Pihtili A, Galle M, Cuhadaroglu C, Kilicaslan Z, Issever H, Erkan F, Cagatay T, Gulbaran Z. Evidence for the Efficacy of a Bioresonance Method in Smoking Cessation: A Pilot Study. Forsch Komplementmed. 2014; 21:239-245.

7. Kostowski W. Współczesna farmakoterapia uzależnienia od nikotyny. Alkoholizm i Narkomania. 2001; 14(1): 129-136.

8. Stead LF, Perera R, Bullen C, Mant D, Hartmann-Boyce J, Cahill K. et al. Nicotine replacement therapy for smoking cessation. Cochrane Database Syst Rev. 2012; DOI: 10.1002/14651858. CD000146.pub4

9. Hajek P, West R, Foulds J, Nilsson F, Burrows S, Meadow A. Randomized comparative trial of nicotine polacrilex, a transdermal patch, nasal spray, and an inhaler. Arch. Intern. Med. 1999; 159: 2033-2038.

10. Beard E, Shahab L, Cummings DM, Michie S, West R. New Pharmacological Agents to Aid Smoking Cessation and Tobacco Harm Reduction: What Has Been Investigated, and What Is in the Pipeline? 2016; 30(10): 951-983.

11. Schnoll RA, Goelz PM, Veluz-Wilkins A, Blazekovic S, Powers L, Leone FT. et al. Long-term nicotine replacement therapy: a randomized clinical trial. JAMA Intern Med. 2015; 175(4): 504511.

12. Prochaska JJ. Nicotine Replacement Therapy as a Maintenance Treatment. JAMA. 2015; 314(7): 718-719.

13. A clinical practice guideline for treating tobacco use and dependence: A US Public Health Service report. JAMA. 2000; 283(24): 3244-3254.

14. Bowker KA. Lewis S, Coleman T, Vaz LR, Cooper S. Comparison of cotinine levels in pregnant women while smoking and when using nicotine replacement therapy. Nicotine Tob Res. 2014; 16(6): 895-898.

15. Forinash AB, Pitlick JM, Clark K, Alstat V. Nicotine replacement therapy effect on pregnancy outcomes. Ann Pharmacother. 2010; 44(11): 1817-1821.

16. Scherphof CS, van den Eijnden RJ, Engels RC, Vollebergh WA. Long-term efficacy of nicotine replacement therapy for smoking cessation in adolescents: a randomized controlled trial. Drug Alcohol Depend. 2014; 140: 217-220.

17. Moore D, Aveyard P, Connock M, Wang D, Fry-Smith A, Barton P. Effectiveness and safety of nicotine replacement therapy assisted reduction to stop smoking: systematic review and meta-analysis. BMJ. 2009; 338: 867-871.

18. Stapleton J, West R, Hajek P, Wheeler J, Vangeli E, Abdi Z. et al. Randomized trial of nicotine replacement therapy (NRT), bupropion and NRT plus bupropion for smoking cessation: effectiveness in clinical practice. Addiction. 2013; 108(12): 2193-2201.

19. Hughes JR, Stead LF, Lancaster T. Antidepressants for smoking cessation. Cochrane Database Syst Rev. 2014; 1. DOI: 10.1002/14651858.CD000031.pub3

20. Hurt RD, Sachs DP, Glover ED, Offord KP, Johnston JA, Dale LC. et al. A comparison of sustained-release bupropion and placebo for smoking cessation. N Engl J Med. 1997; 337: 1195-1202.

21. Richmond R, Zwar N. Review of bupropion for smoking cessation. Drug Alcohol Rev. June 2003;22(2):203-220.

22. De Long N, Hyslop JR, Nicholson CJ, Morrison KM, Gerstein HC, Holloway AC. Postnatal metabolic and reproductive consequences of fetal and neonatal exposure to the smoking cessation drug bupropion. Reprod Sci. 2013; 20(10): 1156-1161.

23. Kautiainen K, Ekroos H, Puhakka M, Liira H, Laine J, Linden K. et al. Retreatment with varenicline is a cost-effective aid for smoking cessation. J Med Econ. 2017; 20(3): 246-252.

24. Coe JW, Brooks PR, Vetelino MG, Wirtz MC, Arnold EP, Huang J. et al. Varenicline: an $\alpha 4 \beta 2$ nicotinic receptor partial agonist for smoking cessation. J Med Chem. 2005; 48(10): 3474-7.

25. Hajek P, McRobbie HJ, Myers KE, Stapleton J, Dhanji AR. Use of varenicline for 4 weeks before quitting smoking: decrease in ad lib smoking and increase in smoking cessation rates. Arch Intern Med. 2011; 171(8): 770-777.

26. Gonzales D, Hajek P, Pliamm L, Nackaerts K, Tseng LJ, McRae TD. et al. Retreatment With Varenicline for Smoking Cessation in Smokers Who Have Previously Taken Varenicline: A Randomized, Placebo-Controlled Trial. Clin Pharmacol Ther. 2014; 96(3): 390-396.

27. Chantix $®$ [package insert]. New York, NY: Pfizer Labs, 2014.

28. Tabex $\AA^{\circledR}$ [package insert]. Sofia, Bulgaria: Sopharma AD, 2016.

29. Vinnikov D, Brimkulov N, Burjubaeva A. A double-blind, randomized, placebo-controlled trial of cytisine for smoking cessation in medium-dependent workers. The Journal of Smoking Cessation. 2008; 3(01): 57-62.

30. West R, Zatonski W, Cedzynska M, Lewandowska D, Pazik J, Aveyard P. et al. Placebo-Controlled Trial of Cytisine for Smoking Cessation. N Engl J Med. 2011; 365(13): 1193-1200.

31. Zhuang Y, Cummins SE, Sun JY, Zhu SH. Long-term e-cigarette use and smoking cessation: a longitudinal study with US population. Tobacco Control. 2016; 25: 90-95.

32. Beard E, Shahab L, Cummings DM, Michie S, West R. New Pharmacological Agents to Aid Smoking Cessation and Tobacco Harm Reduction: What Has Been Investigated, and What Is in the Pipeline? CNS Drugs. 2016; 30(10): 951-83.

33. McRobbie H, Bullen C, Hartmann-Boyce J, Hajek P. Electronic cigarettes for smoking cessation and reduction. Cochrane Database Syst Rev. 2014; 12. DOI: 10.1002/14651858.CD010216. pub2

34. Hughes JR., Stead LF., Lancaster T. Nortriptyline for smoking cessation: a review. Nicotine Tob Res. 2005; 7(4): 491-499.

35. Cinciripini PM, Tsoh JY, Wetter DW, Lam C, de Moor C, Cinciripini $L$, et al. Combined effects of venlafaxine, nicotine replacement, and brief counseling on smoking cessation. Exp Clin Psychopharmacol. 2005; 13(4): 282-292.

36. Sarginson JE, Killen JD, Lazzeroni LC, Fortmann SP, Ryan HS, Ameli N, et al. Response to transdermal selegiline smoking cessation therapy and markers in the 15q24 chromosomal region. Nicotine Tob Res. 2015; 17(9): 1126-1133.

37. Gourlay SG, Stead LF, Benowitz NL. Clonidine for smoking cessation. Cochrane Database Syst Rev. 2004; 3. DOI: 10.1002/14651858.CD000058.pub2

38. Leggio L, Zywiak WH, Edwards SM, Tidey JW, Swift RM, Kenna GA. A preliminary double-blind, placebo controlled randomized study of baclofen effects in alcoholic smokers. Psychopharmacology. 2015; 232(1): 233-243.

39. Oncken C, Arias AJ, Feinn R, Litt M, Covault J, Sofuoglu M, et al. Topiramate for smoking cessation: a randomized, placebocontrolled pilot study. Nicotine Tob Res. 2014; 16(3): 288-296.

40. Cahill K, Stevens S, Perera R, Lancaster T. Pharmacological interventions for smoking cessation: an overview and network meta-analysis. Cochrane Database Syst Rev. 2013. Doi: 10.1002/14651858.CD009329.pub2

41. Ebbert JO, Hatsukami DK, Croghan IT, Schroeder DR, Allen SS, Hays JT, et al. Combination varenicline and bupropion SR for tobacco-dependence treatment in cigarette smokers: a randomized trial. JAMA. 2014; 311(2): 155-163.

42. Ramon JM, Morchon S, Baena A, Masuet-Aumatell C. Combining varenicline and nicotine patches: a randomized controlled trial study in smoking cessation. BMC Medicine. 2014; 12: 172.

43. Koegelenberg CF, Noor F, Bateman ED, van Zyl-Smit R.N, Bruning A, O'Brien JA, et al. Efficacy of varenicline combined with 
nicotine replacement therapy vs varenicline alone for smoking cessation: a randomized clinical trial. JAMA. 2014; 312(2): 155161.

44. Cahill K, Stevens S, Perera R, Lancaster T. Pharmacological interventions for smoking cessation: an overview and network meta-analysis. Cochrane Database of Systematic Reviews. 2013; 5. DOI: 10.1002/14651858.CD009329.pub2

45. Wetter DW, Cofta-Gunn L, Fouladi RT, Cinciripini PM, Sui D, Gritz ER. Late relapse/sustained abstinence among former smokers: a longitudinal study. Prev Med. 2004; 39: 1156-1163.

46. Krall EA, Garvey AJ, Garcia RI. Smoking relapse after 2 years of abstinence: findings from the VA Normative Aging Study. Nicotine Tob Res. 2002; 4 (1): 95-100.

47. Smith P, Weinberger A, Zhang J, Emme E, Mazure C, McKee S. Sex Differences in Smoking Cessation Pharmacotherapy Comparative Efficacy: A Network Meta-analysis. Nicotine and Tobacco Research. 2017; 19(3): 273-281.

48. Hughes JR. Varenicline as a Cause of Suicidal Outcomes, Nicotine \& Tobacco Research. 2015; 18(1): 2-9.

49. Tadrous M, Martins D, Yao Z, Mamdani MM, Juurlink DN, Gomes $\mathrm{T}$, et al. Varenicline and Risk of Self-Harm: A Nested CaseControl Study. PLoS One. 2016; 11(9). DOI: 10.1371/journal. pone.0163681

50. Zyban ${ }^{\circledR}$ [package insert]. Greenville, SC: GlaxoSmithKline, 2011

51. Steensland P, Simms JA, Holgate J, Richards JK, Bartlett SE, Varenicline, an alpha4beta 2 nicotinic acetylcholine receptor partial agonist, selectively decreases ethanol consumption and seeking. Proc. Natl. Acad. 2007; 104(30): 12518-12523.

52. Wouda JA, Riga D, De Vries W, Stegeman M, van Mourik Y, Schetters D, et al. Varenicline attenuates cue-induced relapse to alcohol, but not nicotine seeking, while reducing inhibitory response control, Psychopharmacology. 2011; 216 (2): 267-277

53. Kaminski BJ, Weerts EM. The effects of varenicline on alcohol seeking and self-administration in baboons Alcohol. Clin. Exp. Res. 2014; 38 (2): 376-383.
54. Jorenby DE1, Hays JT, Rigotti NA, Azoulay S, Watsky EJ, Williams KE, Billing CB, Gong J, Reeves KR; Varenicline Phase 3 Study Group. Efficacy of varenicline, an alpha4beta2 nicotinic acetylcholine receptor partial agonist, vs placebo or sustainedrelease bupropion for smoking cessation: a randomized controlled trial. JAMA. 2006; 296: 56.

55. Gonzales D, Rennard SI, Nides M, Oncken C, Azoulay S, Billing CB, Watsky EJ, Gong J, Williams KE, Reeves KR; Varenicline Phase 3 Study Group. Varenicline, an alpha4beta 2 nicotinic acetylcholine receptor partial agonist, vs sustained-release bupropion and placebo for smoking cessation: a randomized controlled trial. JAMA. 2006; 296: 47.

\section{Informacja na temat źródeł finansowania pracy}

Praca powstała w ramach działalności statutowej DS. 186 II Kliniki Psychiatrii i Rehabilitacji Psychiatrycznej Katedry Psychiatrii, Uniwersytet Medyczny w Lublinie

\section{Information regarding funding sources of the research} work

The research work was funded by the basic operatingfunds of the II Department of Psychiatry and Psychiatric Rehabilitation DS. 186, Medical University of Lublin

\section{Corresponding author}

Marcin Olajossy

II Department of Psychiatry and Psychiatric Rehabilitation, Medical University of Lublin tel. 8174884 27, e-mail: olajossy@o2.pl

Otrzymano: 27.04.2017

Zrecenzowano: 05.05.2017,10.06.2018,12.06.2018

Przyjęto do druku: 19.04.2019 